\title{
Correction to: A Black mother's counterstory to the Brown-White binary in dual language education: toward disrupting dual language as White property
}

\author{
Andrea Blanton $^{1} \cdot$ G. Sue Kasun ${ }^{1}$ (D) James A. Gambrell ${ }^{2}$ D $\cdot$ Zurisaray Espinosa $^{1}$
}

Published online: 6 May 2021

○) The Author(s), under exclusive licence to Springer Nature B.V. part of Springer Nature 2021

\section{Correction to: Language Policy https://doi.org/10.1007/s10993-021-09582-4}

In the original publication of the article the author name Zurisaray Espinosa was displayed with incorrect spelling. This has been corrected with this Correction.

The original article has been corrected.

Publisher's Note Springer Nature remains neutral with regard to jurisdictional claims in published maps and institutional affiliations.

The original article can be found online at https://doi.org/10.1007/s10993-021-09582-4.

G. Sue Kasun skasun@gsu.edu

Andrea Blanton andreablanton@gmail.com

James A. Gambrell jgambre2@kennesaw.edu

Zurisaray Espinosa zespinosa1@gsu.edu

1 Georgia State University, Atlanta, GA, USA

2 Kennesaw State University, Kennesaw, GA, USA 